\title{
Deficient Developmental Planning Leading to Water Conflicts across Political Borders: The Way Forward
}

\author{
Elias Salameh ${ }^{1}$, Nadhir Al-Ansari ${ }^{*}$ \\ ${ }^{1}$ University of Jordan, Amman, Jordan \\ ${ }^{2}$ Lulea University of Technology, Lulea, Sweden \\ Email: salameli@ju.edu.jo, ^nadhir.alansari@ltu.se
}

How to cite this paper: Salameh, E. and Al-Ansari, N. (2021) Deficient Developmental Planning Leading to Water Conflicts across Political Borders: The Way Forward. Engineering, 13, 158-172.

https://doi.org/10.4236/eng.2021.133012

Received: February 24, 2021

Accepted: March 22, 2021

Published: March 25, 2021

Copyright $\odot 2021$ by author(s) and Scientific Research Publishing Inc. This work is licensed under the Creative Commons Attribution International License (CC BY 4.0).

http://creativecommons.org/licenses/by/4.0/ (c) (i) Open Access

\begin{abstract}
In this article, Turkey, Iran and Syria in the Middle East area are taken as examples for deficient planning and development of water resources shared with their downstream countries resulting in severe social, economic and political percussions to these neighbors. The current situation in the Middle East with wars against terrorism, uprising of population groups, and COVID-19 Pandemic have not allowed the affected countries Jordan, Iraq and Syria to properly react to the assaults of upstream water development and diversions on their fair shares in the transboundary waters. The rivers' upstream developmental schemes have not taken advantages of recent advanced technological knowhow of water efficient development and use, seemingly because the arising water problems and catastrophes will not affect these upstream countries, but their downstream neighbors. Although, it is by now known that pressurized water conveyance system relative to canals saves $10 \%-20 \%$ of the transmitted water, and drip and sprinkler irrigation require only $40 \%-50 \%$ of the water used in surface and furrow irrigation, that is in addition to agricultural production increases when using advanced management strategies. As enhancing policies, tradeoffs between downstream and upstream countries are thought of as a strategic option to improve the water use efficiency in upstream countries in order to help downstream countries in obtaining their fair shares of the transboundary water resources.
\end{abstract}

\section{Keywords}

Transboundary Water, Deficient Planning, Water Use Efficiency, Middle East, Tradeoffs 


\section{Introduction}

In general, upstream countries of river basins develop much of the basin's water resources for agricultural uses [1] [2] [3] [4] [5]. The planning and development of agricultural schemes mostly suffer from leaky water conveyance systems and outdated irrigation practices, but; nonetheless, they create cheap jobs in agriculture, alleviate poverty and produce local food, which lessens poverty and hunger. That is then reflected in social and economic comfort and hence political stability. Creating job opportunities in the agricultural sector to alleviate poverty and to produce food is of low capital cost, compared to job opportunities in other sectors such as industry (estimated for Jordan at more than 10 folds). Hence, upstream countries resort to developing agricultural projects depending on the available water resources in the upstream areas of river basins using old and, in most cases, outdated methods, without the due consideration that the extracted water is a rightful share of a downstream country. They develop the water resources jeopardizing herewith others' rights in these waters what leads to disputes among countries sharing a river basin followed by conflicts over the water resources which might develop into armed conflicts. That is instead of using advanced technologies, which save much water and may make disputes and conflicts with downstream countries unnecessary.

Technological advancement in the water sector is positively changing the lifestyles of people and societies and adding security to the socio-economics and political comfort of countries, especially those countries of the dry climatic zones of the Globe.

More water in such countries means comfort that is more human and increasing agriculture and industrial production, which result in increasing employment and decreasing poverty and hunger. These are socioeconomic factors which enhancement is badly needed in many developing countries of the world.

Farmers, all over the Middle East area are facing droughts, soil physical deterioration and salinization, groundwater depletion and quality degradation in addition to shortages in water supplies [4] [6]. Optimization of water use by increasing its efficiency requires changing the way water is delivered to farms and the way it is applied in irrigation.

Traditional irrigation ways were used along the Euphrates, Tigris, Diyala, Jordan and Yarmouk Rivers throughout human history, but the problem in these river's basins is that the recent irrigation projects of dam construction, and hydropower generation are designed using the most advanced technologies and only irrigation systems using these structures' water continue to use outdated tradition farming systems. This might indicate that the traditional ineffective irrigation systems were intentionally meant to remain, in order, to deprive the downstream countries of their fair shares in the transboundary water.

Pressurized water conduits, drip and other more efficient irrigation systems such as mulch and greenhouses and advanced agricultural practices, smooth metering, regular irrigation, control systems, soil moisture devices, cameras, tele- 
measurements, leakage detection and monitoring result in more efficient water use. These save water, increase agricultural productivity of a water unit, improving product quality, bringing higher returns to farmers and improve export potentials, improved food security, more secure jobs, and higher personal qualifications' requirements to operate advanced systems [2] [3] [4] [6]. Not to forget here the importance of governmental advanced farming management.

The questions arising; here are can the application of advanced water and agricultural technologies and management tools in the upstream areas of river basins save water so that downstream areas receive their fair shares of that water? What tradeoffs among basin riparian countries can be worked out to achieve fair sharing of water resources? Can such trade-offs lead to fair use of water and win-win situations in a river basin?

\section{Countries}

The Middle East is considered as arid to semi-arid region where the long-term annual rainfall does not exceed $166 \mathrm{~mm} /$ year (Figure 1) [5] [7]-[13]. For this reason, there are about 12 countries have their allocation per capita does not exceed $500 \mathrm{~m}^{3}$ [14] [15]. Climate change, high population growth rate, economic and social development are expected to increase the future demand of water in the region [16]. Water shortage problem in the region is causing friction and tension.

To overcome water shortage problems, countries in the upper parts of the catchments (Turkey, Iran and Syria) of the Tigris and Euphrates basins constructed several dams (Figure 2) and are planning to construct others in future. This reduced the flow of the rivers and negatively affected Iraq, which is located downstream of the two basins.

\subsection{Turkey}

Turkey's policy-makers and planners have since the early 1960s been engaged in policies, strategies and programs to develop the head waters of the Euphrates and Tigris Rivers in their territories for hydropower production and for using

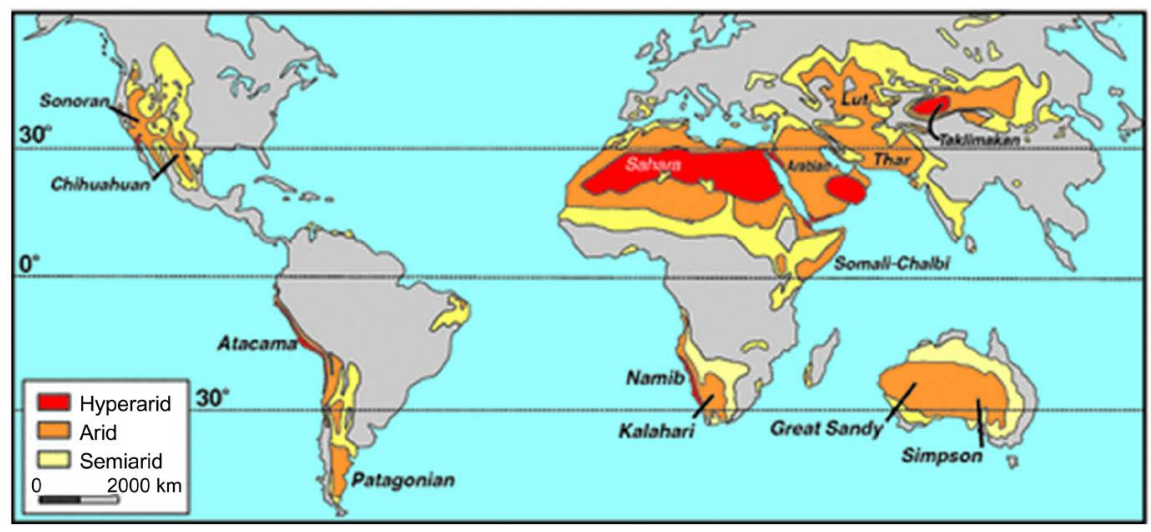

Figure 1. Map of distribution of non-polar arid lands (after [8] [9]). 


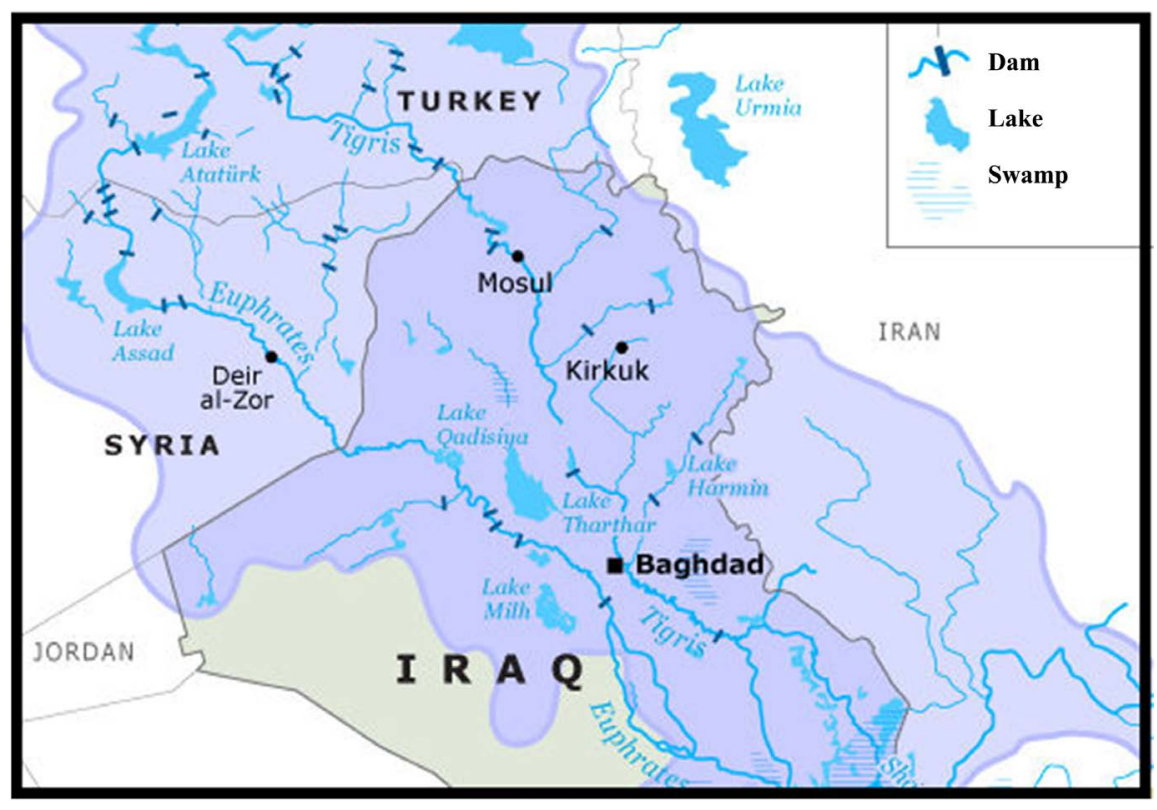

Figure 2. Location of dams within Tigris and Euphrates basins.

the harvested water in irrigation in the underdeveloped southeastern part of the country [3] [4] [17].

Hydropower and irrigation have been planned as tools to reduce imported fuel and foodstuff and to achieve socio-economic development by creating employment, alleviating poverty, and reducing social and political tension, which are believed to increase the political stability of the country [3] [18] [19].

Turkey started its Great Anatolian Project (GAP) in 1977 (Figure 3). It included the construction of 22 dams on the head waters of the Euphrates and Tigris Rivers for hydropower generation and irrigation; to generate 27 billion $\mathrm{kWh} / \mathrm{yr}$ of electric energy and to irrigate 1.8 million hectares of land [3] [4]).

In the meantime, all planned dam projects, including Ilisu dam, have been commissioned. Almost all of these dams are used for irrigation, around half of them for power generation and very few for flood control or drinking water supplies [19].

According to [20], $78 \%$ of the planned hydropower production and $54 \%$ of the irrigation projects are already completed. Water among others is used for the irrigation of cotton and cereals, which consume huge amounts of water.

Generally, water is diverted for irrigation by gravity using open and raised canals with a conveyance efficiency of about $88 \%$. Surface irrigation methods consisting mostly (about 90\%) of furrow and flood irrigation with an average efficiency of $45 \%$ compared to drip and sprinkler irrigation [21] [22] [23].

The water consumption to irrigate one hectare averages $7000 \mathrm{~m}^{3}$ [21] although considering the Mediterranean type of the climate of the area, the area's precipitation of $250-700 \mathrm{~mm} / \mathrm{yr}$ and its potential evaporation of less than $1600 \mathrm{~mm} / \mathrm{yr}$ indicates that not more than half of the really consumed amount of water is required for irrigation when using advanced irrigation methods [21] [22]. 


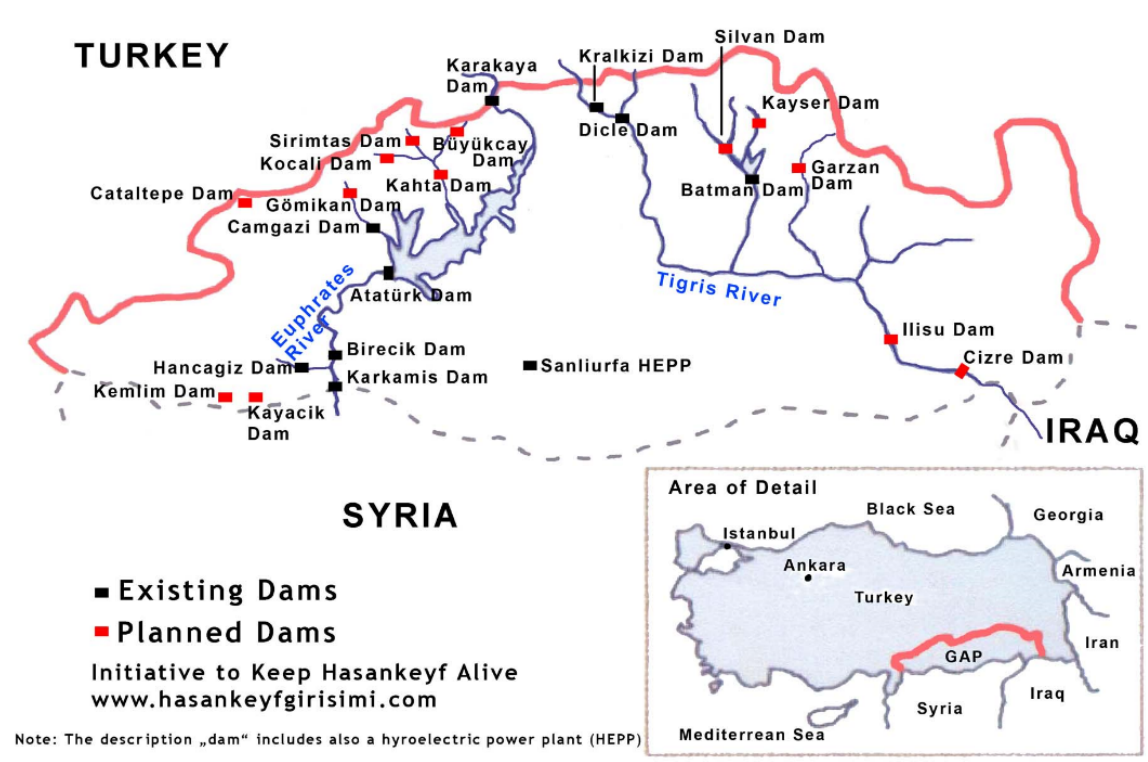

Figure 3. Location of existing and planned dams of GAP in Turkey.

Although many studies urged for holistic integrated developmental projects in the water sector to include conversion of open and raised canals into closed conduits and use of advanced on-farm irrigation practices such as drip irrigation, irrigation water is still used by inefficient methods such as flood irrigation, leaky open canal systems, very modest training programs of farmers and outdated management of projects.

Farmers in Turkey still use and prefer to use surface irrigation methods because of the high capital cost of irrigation pressurized techniques [24] [25], because of the unrestricted availability of irrigation water and because of the lack of farmers of experience in advanced technologies.

If Turkey's GAP irrigation projects would use the technologies of pressurized water conveyance system to farms instead of the open canals only 6160 $\mathrm{m}^{3} /$ hectare will be needed to reach the farms, which is the actual amount reaching farms from the presently released amount of $7000 \mathrm{~m}^{3} /$ hectare through the inadequate conveyance systems. The requirements for a hectare of land under the prevailing climatic conditions should not exceed $3000 \mathrm{~m}^{3} /$ hectare compared to a present use of around $6160 \mathrm{~m}^{3} /$ hectare Calculation is based on [21] [23]. That means that the water use efficiency in irrigation in Turkey is not more than about $42 \%$ and that coincides well with the Turkish percentages of $45 \%$ [25] and $38 \%$ - $48 \%$ for the irrigation systems [22].

Therefore, it does not seem that there is an issue in Turkey reducing the flows of the Euphrates and Tigris Rivers to Syria and Iraq arguing that Turkey needs the water except that Turkey is using the water as a political weapon against Syria and Iraq.

This also indicates that the planning of the GAP project as it is being implemented was deficient and the only bearer of the consequences of such deficient planning are the people of the downstream countries; Syria and Iraq. It is caus- 
ing the heated conflict with Syria and Iraq and depriving their populations of their water as a source of existence, which they used to depend on throughout the last 4 millennia.

\subsection{Iran}

Iran has built on the tributaries of the Tigris River 14 dams (Figure 4) with a total water storage capacity of 15.8 billion cubic meters [17] [19] [26] [27], whereas the Tigris tributaries used to discharge into Iraq an average of only $10-21$ billion cubic meters [14] [17] [19]. The Iranian dams were constructed at distances from the Iran-Iraq borders, which means that the downstream areas' contributions of these dams to the river flow within Iran are not included into the dam's capacity calculations. Therefore, the Iranian dams' total capacity of $15.8 \mathrm{bm}^{3}$ is estimated at around twice the discharges of the Tigris tributaries at these dams' sites.

The dams' water is generally used for irrigation, but many dams also produce hydropower and few are used for domestic water supplies [7] [19].

Irrigation water use efficiency in the different regions of Iran including irrigation in the Tigris catchment average 35\% as compared to $70 \%-90 \%$ irrigation systems efficiency in developed countries [7] [28] [29]. Furrow and basin irrigation are generally the ways irrigation is made. [27] concluded that the all over water use efficiency in irrigation developed from $34.8 \%$ in the 1990 s to $40 \%$ in the 2000 s and to $43.6 \%$ in the 2010 s.

These figures show that if Iran's farmers irrigating their fields from dams constructed on the Tigris River tributaries would use pressurized conveyance systems and drip and sprinkler irrigation at least half of its present volumes can cut

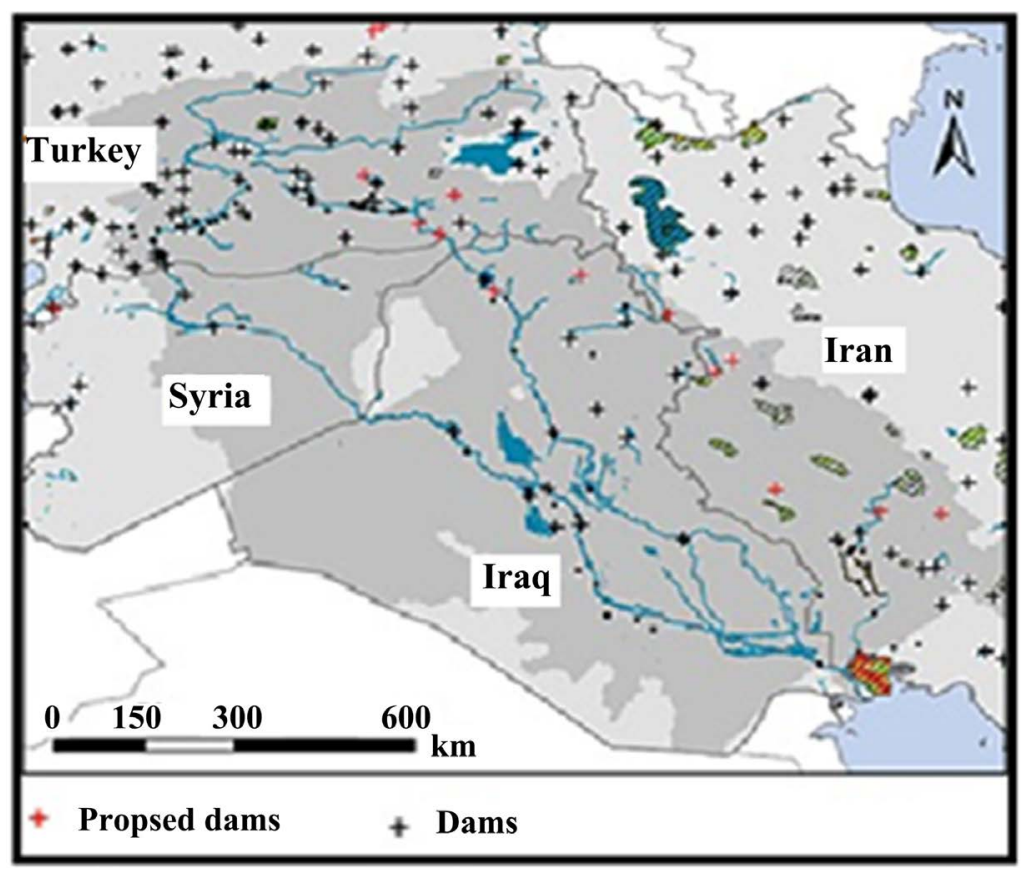

Figure 4. location map of dams in Turkey, Iraq, Syria and Iran. 
their extractions from the Tigris River. The saved water can be released to account for Iraq's fair share in these waters in order to serve farmers alleviating herewith their water shortages created by Iran's dam projects. Such a policy can alleviate social and economic pressures Iraqi farmers are facing and hence enhance political stability in Iraq.

\subsection{Syria}

\section{Yarmouk River}

Syria built on the tributaries and headwaters of the Yarmouk River tens of dams and weirs to harvest as much water as possible from the flood and base flow waters to be mainly used in irrigation (Figure 5). The measured flow of the Yarmouk River at Adasiya, the River entrance into the Jordan Valley, averaged during the 1940s and 1960s around $500 \mathrm{MCM} / \mathrm{yr}$. The Johnston Plan [30] on the sharing the Yarmouk River water (accepted by the Arab League) allocated to Syria from the River flow a fixed amount of $90 \mathrm{MCM} / \mathrm{yr}$, to Israel a fixed amount of $25 \mathrm{MCM} / \mathrm{yr}$ and the rest of the flow, averaging $375 \mathrm{MCM} / \mathrm{yr}$, to Jordan.

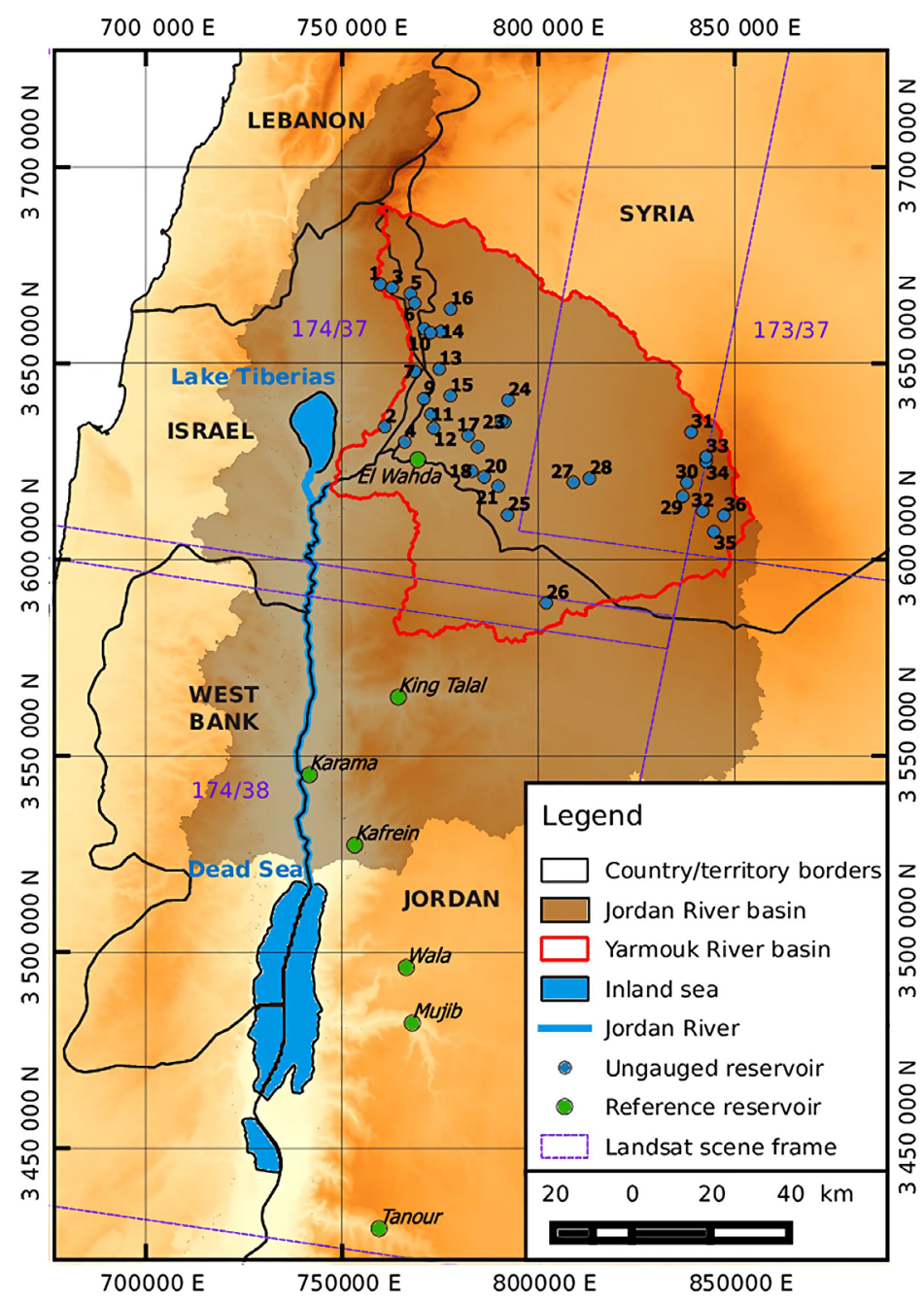

Figure 5. Yarmouk drainage basin. 
In 1987, Jordan and Syria reached an agreement allocating to Jordan 200 $\mathrm{MCM} / \mathrm{yr}$ from the Yarmouk River sources, and both agreed to construct a dam on the Yarmouk River for hydropower generation (mainly to benefit Syria) and for dam's water to be used by Jordan.

But Syria went ahead with the construction of dams and weirs and drilling of groundwater wells so that the flow of the Yarmouk River at present dwindled to a few tens of MCM/yr of flood water.

The by-far major part of the Syrian water extractions from the Yarmouk River catchment surface and groundwater resources is used for irrigation in Syria. According to Syrian country reports [31] Syria extracts from the Yarmouk River Catchment around $500 \mathrm{MCM} / \mathrm{yr}$, herewith, overexploiting the groundwater resources within the Yarmouk River basin and depriving Jordan of around 300 $\mathrm{MCM} / \mathrm{yr}$ of surface and groundwater resources, which before the Syrian extractions used to feed the Yarmouk River or flow into Jordan as groundwater.

In the Syrian Yarmouk catchment, around 22.500 hectares of land are presently irrigated with an irrigation water conveyance efficiency of concrete canals of $75 \%$ and natural earth canals $35 \%-50 \%$. The irrigation water use efficiency of sprinklers is $50 \%-60 \%$ and that of surface irrigation $45 \%-50 \%$ [31].

According to [32] improving irrigation conveyance systems can save as much as $22 \%$ of the presently released water through irrigation canals and when using drip irrigation the savings will be around 56\%. According to Abou Zakhem et al. (2019), improving water management strategies can increase productivity in irrigation and save additional $10 \%-20 \%$ of the water presently used in irrigation.

Some of the given information about irrigation water use efficiency is older than the conflict in Syria, and hence they don't represent the present situation, but generally, the wars in Syria have led to deteriorations in almost all sectors by damage and sabotage including irrigation systems resulting in decreasing water use efficiencies.

Improving irrigation conveyance systems to concrete and pressurized systems, irrigation methods from furrow and flood to pressurize drip and sprinkler irrigation and improved irrigation management will result in major water savings, which according to the above cited figures, is more than $50 \%$ or around 250 $\mathrm{MCM} / \mathrm{yr}$ in the Syrian catchment area of the Yarmouk River.

If this amount of water, is saved it will relieve the overexploited aquifers of the Yarmouk and Azraq catchments in Syria and Jordan and can save the right share of Jordan in the Yarmouk River and in the water resources of the Azraq basin, which is expected to result in improving relations of the two countries, improving the domestic water supply in Jordan leading to comfort in the social, economic and political arena in both countries.

\section{Euphrates and Tigris Rivers}

The three Syrian dams built along the Euphrates River have a total storage capacity of around $16 \mathrm{~km}^{3}$ planned for use in irrigation and electricity generation (Figure 4 and Figure 6). Historically, the Euphrates River used to discharge 


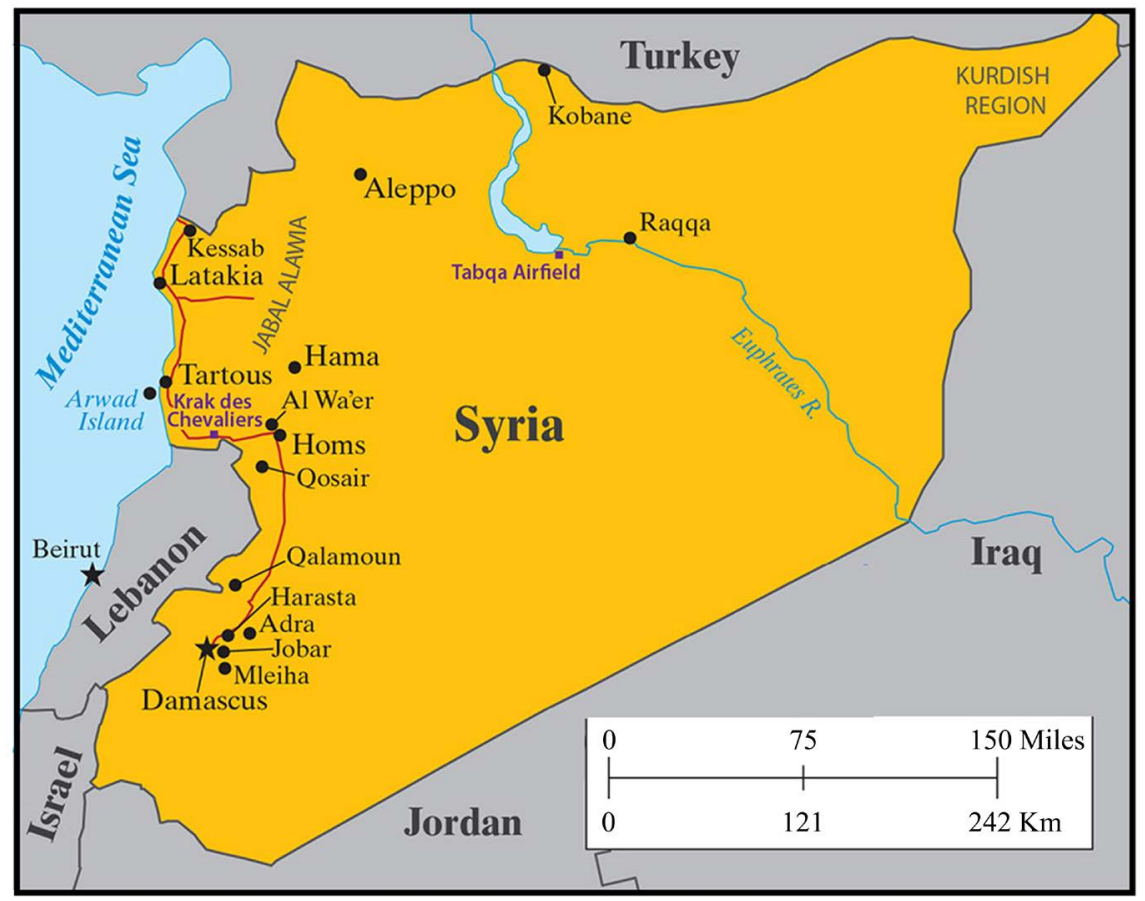

Figure 6. Euphrates river within Syria.

around 28 billion $\mathrm{m}^{3} / \mathrm{yr}$ of water from Turkey into Syria and from their 30 billion $\mathrm{m}^{3} / \mathrm{yr}$ into Iraq [6] [19]).

The unsigned agreement and the protocols of 1987 and 2000 among the three riparian countries for sharing the Euphrates River water allocated a flow of the Euphrates River to Syria of 15 billion $\mathrm{m}^{3} / \mathrm{yr}$ of which $58 \%$ should flow to Iraq [33] [34] [35]. The wars in Iraq and Syria and the sabotage on water systems and irrigation projects during the last two decades restricted the application of the unsigned agreement among the three countries; Turkey, Syria and Iraq. Since about a decade far less water has been flowing through the Euphrates River from Turkey to Syria and from there to Iraq [14] [34] [35].

In addition to the diminishing flow of the Euphrates and Tigris Rivers into Syria, their water quality degraded due to return flows of the Turkish irrigation projects [34] [35]. Irrigation water use efficiency in Syria is very low of about $30 \%-40 \%$ [1] [31] [32] [36].

Applying advanced conveyance and irrigation systems in Syria can save much of the water lost by using the old conveyance gravity systems and flood and furrow application of irrigation water. According to [32] improving irrigation conveyance systems can save as much as $22 \%$ of the presently used water and when using drip irrigation around 56\%. According to [1] improving water management strategies alone can increase productivity in irrigation and save $10 \%-20 \%$ for the water presently used in irrigation.

The wars, sabotage and migration in Syria and the Turkish unfair extractions of the Euphrates water have led to deteriorations in almost all sectors by damage and sabotage, including irrigation systems resulting in decreasing water use effi- 
ciencies [1] [32].

Improving the efficiency of irrigation water use of projects on the Euphrates and Tigris Rivers' water is expected to allow irrigating the lands reclaimed and prepared along these rivers for irrigation and may allow releasing more water into Iraq, which is the country most suffering from upstream water abstractions.

\subsection{Iraq}

Iraq is a downstream country of both the Euphrates and the Tigris Rivers. Before the construction of Turkish, Iranian and Syrian dams, an average of around 21.3 billion $\mathrm{m}^{3} / \mathrm{yr}$ of the Tigris River water used to enter Iraq from Turkey and around 22 billion $\mathrm{m}^{3} / \mathrm{yr}$ from Tributaries of the Tigris River. The Euphrates River used to discharge an average of around 28 billion $\mathrm{m}^{3} / \mathrm{yr}$ from Turkey into Syria and from there around 30 billion $\mathrm{m}^{3} / \mathrm{yr}$ into Iraq [6] [19] [35].

The actual present flow of the Euphrates River to Syria is around 15 billion $\mathrm{m}^{3} / \mathrm{yr}$ of which $58 \%$ should be allocated to Iraq [33]. The wars in Iraq and Syria and the sabotage on water systems and irrigation projects during the last two decades restricted the application of the agreement between the three countries.

Dams in Iran's capture all the flood and base flow water of the tributaries of the Tigris and almost no water reaches Iraq, from these tributaries. In addition, the tributaries of the Tigris in Turkey with an average discharge of 21.3 billion $\mathrm{m}^{3} / \mathrm{yr}$ into Iraq stopped almost completely, especially after the construction of Iliso dam on the Tigris River.

Iraq has built on the Rivers Euphrates, Tigris and its tributaries 7 main dams (Figure 7) with a total capacity of 110 billion $\mathrm{m}^{3}$, generally for irrigational uses, flood control and modest hydropower generation [19].

Historically, Mesopotamia, the Tigris and Euphrates lowlands were irrigated by the two rivers' water by gravity flow and gravity conduits, which for their times were the modern innovations in irrigation techniques [37] [38]. Concrete canals have replaced much of these old irrigation systems, but gravity flow is still the major way of applying irrigation water with an efficiency of irrigation systems of around 32\% [39]. Since 2006 not much has improved in the water use efficiency. The political and security situation in the country with all its implication to the government, society, population and economy has not much helped in improving the water use efficiency in agriculture by introducing modern irrigation techniques, pressurized water systems and evaporation reduction from water storage facilities.

The impacts of internal conflicts in Iraq since about two decades have rigorous negative impacts on the agricultural sector with huge population movements, damage to water conveyance systems and irrigation infrastructure with all their social and economic implications.

In the early years of the 21 century, before the armed conflicts, irrigation water use efficiency was estimated at 30\% - 40\% [40]. The low efficiency is a result of outdated water conveyance systems, e.g. earthen canals, flood irrigation, improper governmental and on farm management and free water. Farmers' low 


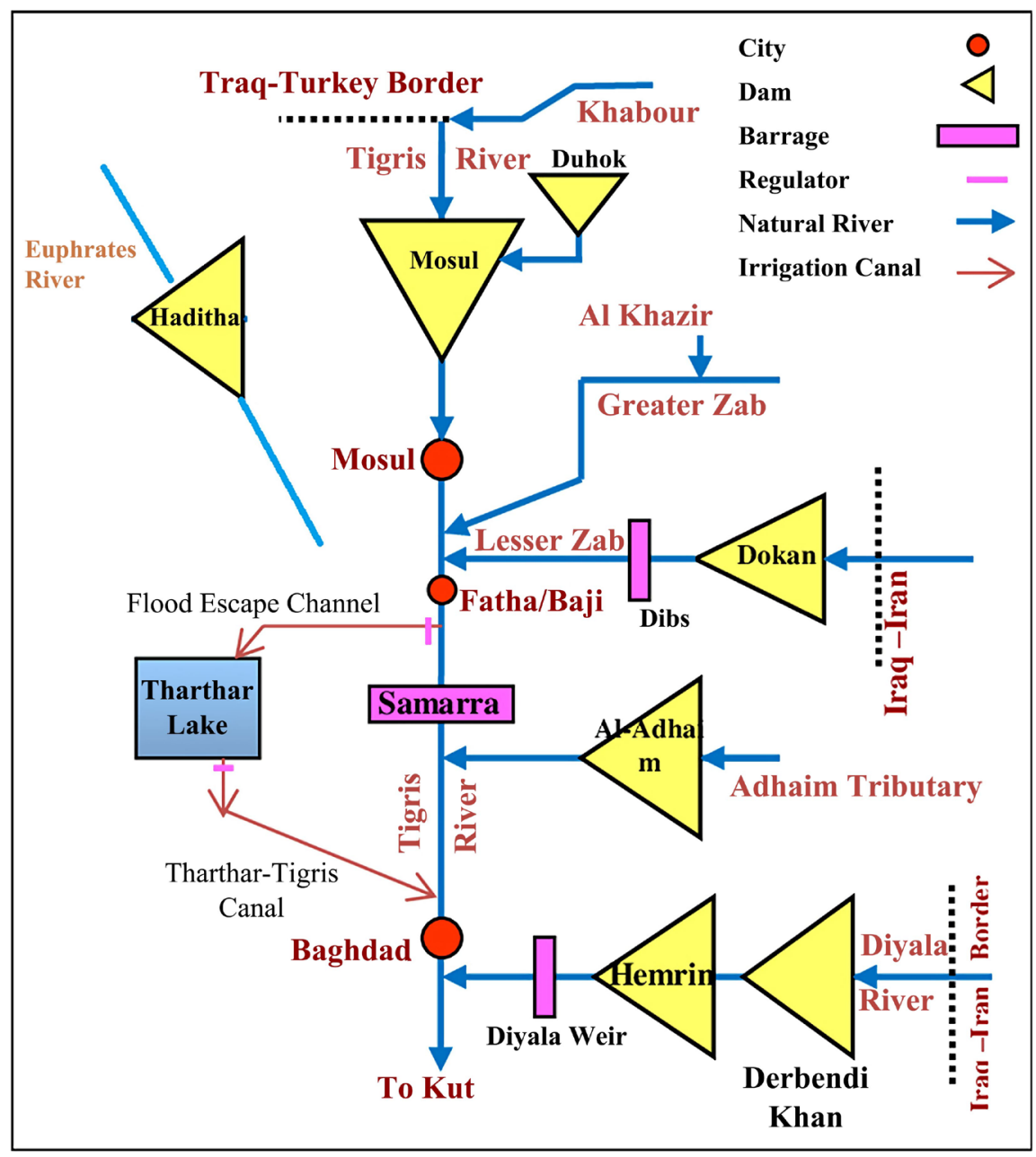

Figure 7. Main dams in Iraq.

farming technology, improper practice of intermittent irrigation and lack of agricultural inputs are some of the other reasons given for low productivity.

Pollution from agricultural and domestic sources seriously affects water quality. In Iraq, the Euphrates suffers from severe salinity that increases in the course of the river [35].

Nonetheless, Iraq is a downstream country, which water extractions have no impact on the downstream areas, and any excess water can only be lost to the sea (Arabian Gulf). Hence, improving Iraq's water use efficiency can only have positively an impact on the country itself and not on any other country. It is not like Turkey, Iran and Syria, which water extractions can affect other countries lying downstream.

Improving water use efficiency will benefit Iraq by increasing the available water resources, which can be used to irrigate additional land, knowing that only about $64 \%$ of the cultivable land is irrigated at present [19] [41]). Improving the water use efficiency will result in creating jobs and increasing local food production, which will have positive implications on the social, economic, environmental and political situation of the country [5] [6] [19] [40] [41]. 


\section{Discussion and Conclusions}

Increasing demand for water in the Middle East area led river-upstream countries to develop whatever they can, the water resources within their reaches irrespective of the fair shares of downstream countries in the transboundary water with huge ramifications to the down-stream countries with detriments to their social, economic and political stability.

It also seems that most conflicts between river basin countries are the result of, generally, failing of upstream countries to introduce technologies in water conveyance systems and in the inefficient application of water in the agricultural sector depriving downstream countries of their fair share in the basin's water. Also a policy can be best described as "Deficient Planning and Development".

Solutions to transboundary water conflicts cannot be easily achieved by "business as usual". New thinking must be there. Integrated river basin-wide management, considering all social, economic conditions and introducing technological advancement with trade-offs can be the only basis to build on to achieve fair sharing of basin's water resources and cooperation towards win-win situations.

Applying advanced water technologies to save water (generate additional water) by using water more efficiently and in applying "Integrated water resources management" can be technically, economically and socially afforded by the different societies. Timely application of such technologies is expected to foster social and economic stability in a country, to achieve political comfort and to lead to cooperation between countries of a river basin.

Generally, earthen gravity and fewer concrete canals transfer the water from reservoirs or river course to farms with losses of $10 \%-20 \%$ of the transferred water quantities. Surface irrigation by land flooding and furrow irrigation is generally the way water which is applied to fields, which means a water use efficiency of $30 \%-40 \%$, compared to drip and sprinkler irrigation [2] [25] [41] [42].

Traditional irrigation methods do not require much investment and knowhow what is allowing the traditional irrigation systems to still dominate the irrigation sector worldwide, although advanced irrigation systems not only improve water use efficiency but also increase the productivity of a water unit.

The questions this article poses to upstream countries are:

- Are we allowed to take advantages and apply advanced water technologies only partly because that is more appealing to our situation irrespective of percussions to other users or water sharing parties?

- Is it not inhuman to develop and use water by obsolete methods and ways irrespective of their harmfulness to other water users and sharing parties?

Trade-offs

- Joint settlement of the Kurdish question;

- Construction of new oil and gas pipelines from Iraq, Saudi Arabia or the Gulf States through Turkey to Europe and Iranian pipelines to the Mediterranean; 
- Agreements to produce agricultural goods within the river catchments in coincidence with the prevailing climate to maximize production and to exchange agricultural products among the catchment countries;

- Paying of nominal cost per cubic meter of water by downstream countries to upstream countries for regulating water flows prohibiting flood and flash flows by the construction of dams;

- Special trade agreements:

- The GCC, Saudi Arabia, and Jordan favor Turkish and Iranian agricultural products compared to those of other countries;

- Giving certain privileges to Turkish and Iranian airlines' flights to Africa crossing the Middle East and/or North African states;

- Oil imports of Turkey from Syria Iraq, Saudi-Arabia and the Gulf States at preferable price.

\section{Conflicts of Interest}

The authors declare no conflicts of interest regarding the publication of this paper.

\section{References}

[1] Abou Zakhem, B., Al Ain, F. and Hafez, R. (2019) Assessment of Field Water Budget Components for Increasing Water Productivity under Drip Irrigation in Arid and Semi-Arid Areas, Syria. Irrigation and Drainage, 68, 452-463. https://doi.org/10.1002/ird.2286

[2] Nazaria, B., Liaghatb, A., Akbaric, M.R. and Keshavarzd, M. (2018) Irrigation Water Management in Iran, Implications for Water Use Efficiency Improvement. Agricultural Water Management, 208, 7-18. https://doi.org/10.1016/j.agwat.2018.06.003

[3] Bilgen, A. (2018) Turkey's Southeastern Anatolia Project (GAP): A Quantitative Review of the Literature. British Journal of Middle Eastern Studies, 47, 652-671. https://doi.org/10.1080/13530194.2018.1549978

[4] Bilgen, A. (2020) Politics of Turkey's Ongoing Hydroelectric Projects. Journal of Middle Eastern Studies, 47, 652-671. https://doi.org/10.1080/13530194.2018.1549978

[5] WB World Bank (2017) Iraq Country Water Resource Assistance Strategy, Addressing Major Threats to People's Livelihoods. World Bank No 36297.

[6] Al-Ansari, N. (2016) Hydro Geopolitics of the Tigris and Euphrates Basins. Engineering, 8, 140-172. https://doi.org/10.4236/eng.2016.83015

[7] FAO (2016) Country Water Report, Iraq 2016. Food and Agriculture Organization of the United Nations, Rome. http://www.fao.org

[8] Biswas, A.K. (1994) International Waters of the Middle East from Euphrates-Tigris to Nile.

[9] Meigs, P. (1953) World Distribution of Arid and Semi-Arid Homoclimates. In: UNESCO, Ed., Reviews of Research on Arid Zone Hydrology, UNESCO, Paris, 203-210.

[10] Maliva, R. and Missimer, T. (2012) Aridity and Drought. In: Arid Lands Water Evaluation and Management. Environmental Science and Engineering (Environmental Engineering), Springer, Berlin, 21-39. 
https://doi.org/10.1007/978-3-642-29104-3 2

[11] Roger, P. and Lydon, P. (1995) Water in the Arab World. Harvard University Press, Cambridge.

[12] Allan, T. (2001) The ME Water Question. I.B. Tauris Publishers, London.

[13] Al-Ansari, N. (1998) Water Resources in the Arab Countries: Problems and Possible Solutions. UNESCO International Conference on World Water Resources, Paris, 6 June 1998, 3-6.

[14] Al-Ansari, N. (2013) Management of Water Resources in Iraq: Perspectives and Prognoses. Engineering, 5, 667-684. https://doi.org/10.4236/eng.2013.58080

[15] Barr, J., Grego, S., Hassan, E., Niasse, M., Rast, W. and Talafré, J. (2012) Regional Challenges, Global Impacts. In: Managing Water under Uncertainty and Risk, UN World Water Development Report 4, Chapter 7, United Nations Educational, Scientific and Cultural Organization, Paris.

[16] Cherfane, C.C. and Kim, S.E. (2012) Arab Region and Western Asia, UNESCWA. In: Managing Water under Uncertainty and Risk. UN World Water Development Report 4, Chap. 33, United Nations Educational, Scientific and Cultural Organization, Paris.

[17] Al-Ansari, N. (2019) Hydro Geopolitics of the Tigris and Euphrates. In: Mustafa, Y., Sadkhan, S., Zebari, S. and Jacksi, K., Eds., Recent Researches in Earth and Environmental Sciences Part of the Springer Proceedings in Earth and Environmental Sciences Book Series (SPEES), Springer, Berlin, 35-70.

https://doi.org/10.1007/978-3-030-18641-8 4

[18] Lombardo, J. (2020) The Power and Policies of Turkey's Hydroelectric Projects-An Interview with Dr. Arda Bilgan. The Turkish Heritage. Organization 2020.

https://www.turkheritage.org/en/publications/analysis-by-tho-contributors-and-liai sons/the-power-and-politics-of-turkeys-ongoing-hydroelectric-projects--an-intervi ew-with-dr-arda-bilgen-9175

[19] FAO (2009) Aquastat Transboundary River Basins-Euphrates-Tigris River Basin. Food and Agriculture Organization of the United Nations (FAO), Rome.

[20] GAP-BKI Bilgen, A. (2019) The Southeastern Anatolia Project (GAP) in Turkey. An Alternative Perspective on the Major Rationales of GAP. Journal of Balkan and near Eastern Studies, 21, 532-552. https://doi.org/10.1080/19448953.2018.1506287

[21] Cakmak, E. (2010) Agricultural Water Pricing, Turkey. In: Sustainable Management of Water Resources in Agriculture, OECD Publishing, Paris, 28 p. https://doi.org/10.1787/9789264083578-14-en

[22] Cakmak, B. (2004) Agricultural Water Use in Turkey. Water International, 29, 257-264. https://doi.org/10.1080/02508060408691776

[23] Republic of Turkey Report (2013) Agricultural Water Uses and Productivity in Turkey. The Republic of Turkey, Ministry of Food, Agriculture, and Livestock. http://www.comcec.org/wp-content/uploads/2015/07/Turkey1.pdf

[24] Cevik, B., Kirda, C. and Kodal, S. (2000) Irrigation Tools, Methods and Organization. Agricultural Engineering V. Technical Congress, Ankara, Vol. 1, 231-258.

[25] Buyukcangaz, H., Demirtas, C., Yazgan, S. and Korukc, A. (2007) Efficient Water Use in Agriculture in Turkey: The Need for Pressurized Irrigation Systems. Water International, 32, 776-785. https://doi.org/10.1080/02508060.2007.9671997

[26] Badawi, T. (2020) Iran's Upstream Hegemony and Its Water Policies towards Iraq. Commentary, Italian Institute for International Political Studies ISPI.

[27] Badawi, T. (2020) The Impacts of Climate Change and Sanctions on Iran's Wa- 
ter-Food Security Nexus. Revisiting Natural Resources in the Middle East and North Africa. European University Institute.

[28] Abbasi, F., Sohrab, F. and Abbasi, N. (2017) Evaluation of Irrigation Efficiency in Iran. Irrigation and Drainage Structures Engineering Research, 17, 113-128.

[29] Madani, K. (2014) Water Management in Iran, What Is Causing the Looming Crisis? Journal of Environmental Studies and Sciences, 4, 315-328.

https://link.springer.com/article/10.1007/s13412-014-0182-Z https://doi.org/10.1007/s13412-014-0182-Z

[30] Wikipedia (2021) Jordan Valley Unified Water Plan. https://en.wikipedia.org/wiki/Jordan_Valley Unified Water_Plan

[31] Kaisi, A., Yasser, M. and Mahrouseh, Y. (2005) Irrigation System Performance: Syrian Country Report. In: Lamaddalena, N., Lebdi, F., Todorovic, M. and Bogliotti, C., Eds., Irrigation Systems Performance, CIHEAM, Bari, 179-192. http://om.ciheam.org/om/pdf/b52/05002258.pdf

[32] Fader, M., Shi, S., von Bloh, W., Bondeau, A. and Cramer, W. (2016) Mediterranean Irrigation under Climate Change, More Efficient Irrigation Needed to Compensate for Increases in Irrigation Water Requirements. Hydrology and Earth System Sciences, 20, 953-972. https://doi.org/10.5194/hess-20-953-2016

[33] Schmandt, J. and Kibaroglu, A. (2016) Sustainability of Engineered Rivers in Arid Lands: Euphrates-Tigris and Rio Grande/Bravo. University of Texas, Austin/LBJ School of Public Affairs Policy Research Project No. 190.

[34] Al-Ansari, N., Ammar, A.A. and Knutsson, S. (2015) Iraq Water Resources Planning, Perspectives and Prognoses. International Conference on Civil and Construction Engineering, Jeddah, 26-27 January 2015, 32 p.

[35] UN-ESCWA and BGR (United Nations Economic and Social Commission for Western Asia; Bundesanstalt für Geowissenschaften und Rohstoffe) (2013) Inventory of Shared Water Resources in Western Asia. Beirut.

[36] Yigezu, A.Y., Ahmed, M., Shideed, K., Hassan, A., El-Shater, T. and Al-Atwan, S. (2013) Implications of a Shift in Irrigation Technology on Resource Use Efficiency: A Syrian Case. Agricultural Systems, 118, 14-22. https://doi.org/10.1016/j.agsy.2013.02.003

[37] Foster, B.R. and Foster, K.P. (2011) Civilization of Ancient Iraq. Princeton University Press, Oxford.

[38] Sousa, A. (1983) Mesopotamian Civilization-In the Light of Irrigation Agricultural Projects, Recent Archeological Discoveries and Historic Resources. 2 Volumes. Al-Huriya Printing House, Baghdad.

[39] WB World Bank (2006) Iraq-Country Water Resource Assistance Strategy, Addressing Major Threats to People's Livelihoods. Water, Environment, Social and Rural Development Department Middle East and North Africa Region. http://documents.worldbank.org/curated/en/944501468253199270/pdf/362970IQ

[40] SWRLI (2015) Government's Strategy for Water and Land Resources in Iraq (SWRLI). T-ZERO. Energy Water and Architecture, (2015). National Strategy for Water and Land Resources Management for Iraq for the Period 2015-2035.

[41] FAO (2018) Iraq, Restoration of Agriculture and Water Systems Sub-Programme 2018-2020. FAO, Rome, 110 p.

[42] Jha, N.K., Malla, R., Sharma, M., Panthi, J., Lakhankar, T., Nir, Y., Krakauer, T.N.Y., Pradhanang, S.M., Dahal, P. and Shrestha, M.L. (2016) Impact of Irrigation Method on Water Use Efficiency and Productivity of Fodder Crops in Nepal. Climate, 4, 4. https://doi.org/10.3390/cli4010004 